Facilitating implementation of Total Quality Management

\title{
through Information Technology
}

RAYA MUSLIM SADIK

Business and Information Technology Lecturer.

Master of Mechatronics Engineering, University of Technology, Baghdad- Iraq rayasadik@ gmail.com

\begin{abstract}
Total Quality Management is a plan or a system that is based on some quality tools that helps a company to maintain their goals and high standard of work and operations. Information technology is a growing field in countries like United Arab Emirates, Saudi Arabia, Pakistan, etc. They should implement and facilitate their workers who are working in operations field with the total Quality management tools. It will result in better and efficient work. It will ultimately help in producing the better result
\end{abstract}

\section{KEYWORDS}

Total Quality Management- Information Technology- Effectiveness- Efficiency - Better Operations- Quality tools

\section{INTRODUCTION}

Total Quality Management is the term that is used in operational management; in short it is for customer satisfaction by a continuous improvement of a company or a firm's employers. Every organization is only focused on customer satisfaction and product/ service quality. So, there are some quality tools that are important in operational management.

The first tool in total quality management is the "Check sheet", it's an organized way of presenting the data in a form of a table. The second tool is "Scattered diagram" which is a graph that depicts some values in a form of dots in which one value is vs other value. The third tool that includes in TQM is "cause and effect diagram", is a tool that shows the process and result of it in a form of a specific diagram. The fourth tool is named as "Pareto chart", this tool is used for identification and finds the problems in a certain process. The fifth tool is "Flowchart", that is in a form of a chart in a process form. The sixth tool is "Histogram", this tool is a chart that tells the distribution of frequency of occurrence of a variable or an amount. The last tool of TQM is "Statistical process control chart", it's a graph that is used for statistical analysis in which the values are placed on the horizontal axis. So, basically, these 7 tools are helpful in improving total quality management. Information System (IT) is the study of systems, windows and understanding the language of computers (storing and sending information within or to other systems). It is the most emerging field for the past few years and coming years is the time of creativity and IT. As you all can see that now we can book a ride using one application, you can have food with one click or you can book a room in a hotel easily, this is all because of "Information technology". There are highly paid jobs for the students who actually know about IT.[1] As the world is emerging and developing day by day, new information technology is popping up in this competitive market and businesses are focusing to gain the competitive advantages. To learn more about IT, the business should hire employees who actually know about new information technology because they can easily cope up with the challenges this competitive market.

TQM involves the implementation of quality control assurance and then we move to total quality management. So, quality control is done by inspections, we can use information technology to inspect the product and procedure we are using by benchmarking it. We can also assure the quality by keeping regular inventory and sales record and that again is done with the help of information systems.

All the 7 tools of total quality management can be used to help if information systems they get their inputs through information system and give their outputs through information system too. [2]

\section{EXAMPLES OF QT-IS}

The best examples of this may include the biometric systems in the offices and universities are the information system implementing total quality management. It is assuring the best quality of security through an information system. Nowadays, a new attendance system has been introduced in offices and especially banks; they are also implementing total quality management through information systems. The main reason behind it is to ensure the presence of the staff by a quality system. One more example of implementation of TQM through Information system can be the enterprise resource planning (ERP) that is software used by many companies to gather all the information related to sales, promotions, accounts, etc., which was once gathered in a form of data in register, now, is entered and gathered through smart software. It is again an example of information system implementing through quality tools (QT). [3] 


\section{RESEARCH QUESTIONS}

The study needs to answer these questions:

1) How TQM helps in facilitating information systems??

2) Will implementing TQM results in efficiency of information system?

3) How a better quality tools does helps in customer satisfaction?

\section{LITERATURE REVIEW}

Total quality management is quality tools that are used by a company to produce efficient products and services and for their customer satisfaction. Information technology is a system that is used by the companies to store and sending information within or outside the systems. It is a language of the computer. This is emerging world and competitive environment businesses and companies are working and developing a strategy to become low-cost producers and to differentiate them from other competitors, they are producing good and quality goods and services. To be better and different, businesses come up with quality. Effective and efficient use of technology is playing an essential role in company's success. By the time, almost all the functions in an organization have been using some kind of technology.

According to an article by A.Z. Siam, K. Alkhateeb and S.Al-Waqqad (2012), it says that the main goals of total quality management in information system is for the upper management of an organization should commitment to place quality as a top priority, to develop a quality culture and continuous commitment to improve employees' capabilities and work processes through training and benchmarking respectively. There nine dimensions of the quality management system that are supported by IT and it includes leadership, strategic planning process, output quality assurance, important innovations, information and analysis, human resource utilization, customer satisfaction and quality results. [4]

There is one field that is diversified from QT and IS named as Management information system (MIS).

It is all about managing the systems through an information system. According to an article by G. M. Hoffman (1978), the main function of an MIS is to capture data from events in the real world, process the data into information useful to a manager, and transmit the information to him in a timely and useful way. The quality of a good MIS is consistency, reliability, and clarity of presentation. They have some important parts such as tools, people, data and the whole process. Tools in management information system are the main and important things are required to run a whole system. People are the support system are the involved in the system. Data is the process information and last is the whole process of a system. Therefore, they require a specific management to run a system and these are essential parts to successfully run an information system.

According to an article by J. E. Scott (2000), information technology and tools are used to increase productivity and it can only be increased by a good management. For example, drive sector tracking systems evaluate suppliers' quality, on-time delivery, and other performance attributes for quarterly reviews. This is only done by using quality tools through information technology.[5]

The information system is so important to maintain and improve organizational agility and firm performance. Information systems in a firm are expected to directly enhance entrepreneurial and adaptive organizational ability. According to an article by A. Chakravarty, R. Grewal, V. Sambamurthy (2013), and Information technology should and do enhance organizational performance; building on this logic, we propose that IT competencies facilitate the positive links between agility and firm performance. Basically, it says that the information technology enhance the ability of productivity in a firm and implementing total quality tools will lead to a better firm's performance. [6] The best and simplest examples for implementation of total quality management through information system are "Uber". Uber is an information system designed with the help of quality tools for the customer satisfaction and productivity. The main function of Uber is to call or book a car with one click. All you have to do is download an app for it. Another example of it can be the security systems in university, offices and corporate sectors. They have all your data in your QR codes and you scan the card on that machine and automatically attendance will be marked. It's an information system designed with the help of quality tools for better job performance and to enhance the job productivity.

\section{METHODOLOGY}

I have done this research by questionnaires that have been answered by the teachers and students of operations department at University of Dubai. I have made these 7 questions just to ask the faculty and students about what they think of total quality management through information technology. After preparing a questionnaire, I have distributed it to some teachers and students. The main reason of distributing them between the experienced and the people who actually know about this topic and distributing it in between the people who are not well aware of these terms that well was to take a look on their point of view. Their view of what makes a difference if a firm implements quality tools through 
information system and what is the future of these two together. There were some questions about the options of yes or no; some questions had three choices to choose. More than 4 questions were openended questions. They have to share their thoughts. 10 people have attempted it and shared their thought.

\section{PARTICIPANTS}

I have distributed this research paper questionnaire among 10 people. 3 were faculty members and 7 were students of University of Dubai. The reason for sharing it among people was to see their thought on this topic of facilitating implementation of total quality management through an information system, its present emergence in the firms and its future.

\section{RESULTS}

The topic of my research paper is "Facilitating implementation of total quality management through information technology". In this research, I have researched about the changes that have been taken place with the use of total quality management through information technology and what is the future of it. I have distributed this questionnaire survey among 10 people. 3 were the teachers of University of Dubai in operations field and other were the students of operations major. There were 4 open-ended questions, 2 were yes or no questions and one was with different options to choose. My first question in the questionnaire was "does total quality management plays a vital role in the corporate image"? And the answers were of yes or no to choose. Figure 1- Shows all person chooses yes for this question that means every person in the field of operations believe that yes, using quality tools and total quality management does affect the corporate image in a good way.

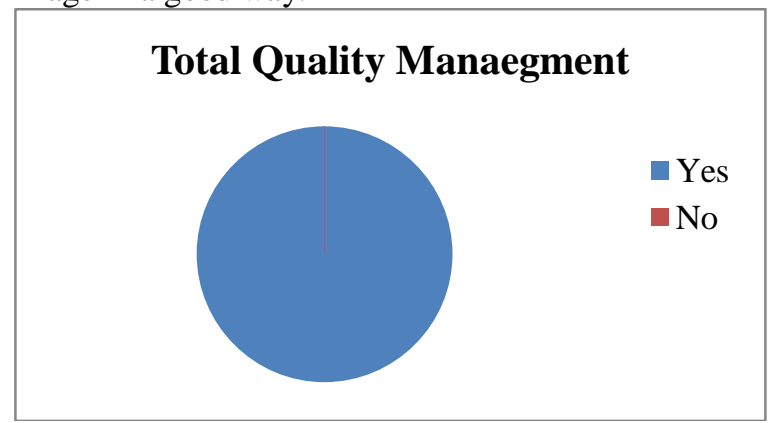

Figure (1) Participations Response to the First Question

The second question that I asked was "why total quality management and information technology is necessary for a company"? I have three options for this, one was managerial efficiency, improving productivity and the third one was both. Three people choose "improving productivity, two people choose managerial efficiency and 5 people voted for both as shown in Figure 2. It means half of the people think, using total quality management and information technology in a company is very necessary for both improving the productivity of the company and for managerial efficiency.

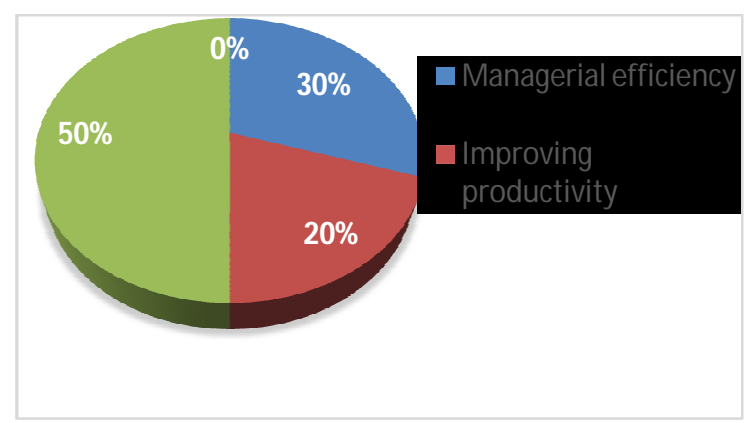

Figure (2) Participations Response to the Second Question

The third question in my research survey was an open-ended question. I asked that "how do better quality tools help in customer satisfaction? There were different answers to this question, some were saying for the developing business cases for WPD, developing the charter and assuring the quality of an organization. Another answer to this question was good quality attracts customers that mean assuring quality and it will lead to customer focus. A guy said that it will provide the hassle-free environment in terms of workload, efficiency in value deliverance to a customer and competitive edge.

The fourth question that asked them was a yes or no question and the question was "will implement total quality management results in the efficiency of the information system?" Everyone voted for yes. It means yes, implementation of TQM will and do result in efficiency of an information system.

The fifth question in the questionnaire survey was an open-ended question and it was how TQM helps in facilitating information system? There were some answers like to increase productivity and excellence of the firm, a requirement to good standards, an introduction of the new process in integration knowledge area, for management and controlling purpose and they can be managed well, for managing quality, data and stocks as well.

My sixth question was to share one example of implementation of total quality management through information technology and that example is working effectively in their respective field. So, they gave an example of Nestle feedback that is printed on their products, Universities and colleges quality by biometric system and empower module, big brands are using MRP, MRP II and ERP for their quality assurance and customer satisfaction etc. 
My last question in the research survey was what future of quality tools and information technology is together. The answer to this question was that they have a direct relation. You would definitely need something related to Information technology in quality tools and quality tools get input from information technology. They would need together in the development of more applications in future and integration (systematic) for the problem solving of total quality tools.

\section{CONCLUSION}

As the completion in the world is increasing. It's two brands or organization competing with one another. Quality management in an organization is very much needed and that will be the point of differentiation. Information technology has changed people's lives in a good way. It has made life much easier and simpler. So, big firm's wants to make their work easier too. Implementation of total quality management through information technology will help in quality assurance of an organization and the quality assurance will result in better performance of an organization. Implementation of total quality management will result in efficiency of information system as well. Information technology is a tool that is used for the better quality of the firm and good customer relation.

\section{REFERENCES}

[1]https://www.rug.nl/research/portal/files/10216022/ c2.pdf

[2]http://thescipub.com/pdf/10.3844/ajassp.2012.666. 672

[3]https://www.ukessays.com/essays/management/rel ationship-between-total-quality-management-andinformation-systems-management-essay.php

[4] Siam, A. Z., Alkhateeb, K., \& Al-Waqqad, S. (2012). The role of information systems in implementing total quality management. American Journal of Applied Sciences, 9(5), 666.

https://doi.org/10.3844/ajassp.2012.666.672

[5] Scott, J. E. (2000). Facilitating interorganizational learning with information technology. Journal of Management information systems, 17(2), 81-113.

https://doi.org/10.1080/07421222.2000.11045648

[6] Chakravarty, A., Grewal, R., \& Sambamurthy, V. (2013). Information technology competencies, organizational agility, and firm performance: Enabling and facilitating roles. Information Systems Research, 24(4), 976-997.

https://doi.org/10.1287/isre.2013.0500

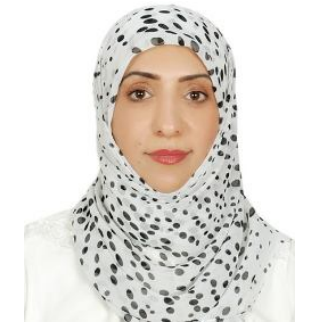

Raya Muslim Sadik received the

M.S.C in Mechatronics Engineering at University of Technology, in( 2000)- BaghdadIraq, she has been teaching Business and Information Technology courses since 2001; She is interested in the following Fields (Total Quality of Management ,Knowledge Management, Management information system 